European Journal of Probation

University of Bucharest www.ejprob.ro

Vol. 4, No.3, 2012, pp $54-68$

ISSN: $2006-2203$

\title{
What works for irregular migrants in the Netherlands?
}

\author{
Miranda Boone ${ }^{1}$ \\ Mieke Kox
}

\begin{abstract}
This contribution provides an overview of the extent to which rehabilitation instruments and opportunities are accessible for irregular migrants who are serving a criminal sanction in the Netherlands. It shows that irregular migrants are largely excluded from criminal sanctions that have rehabilitation as a central aim and from rehabilitation opportunities that are provided during the implementation of criminal sanctions. These findings raise questions concerning the legal legitimacy of largely excluding irregular migrants from rehabilitation opportunities and the way in which irregular migrants prepare themselves for their return to society in practice.
\end{abstract}

Keywords: Irregular migrants - Foreign prisoners - Rehabilitation - Community sanctions - Probation Early release

\section{Introduction}

The rehabilitation principle is a fundamental principle of penitentiary law in Europe that is enshrined in international and national legislation. ${ }^{2}$ It is considered an important principle due to reasons of humanity and effectiveness: the implementation of this principle creates more humane detention conditions. And, according to numerous academic criminological studies, it also helps to prevent recidivism which is considered an important aim of sentencing (for example, McNeill, Raynor and Trotter 2010 and several contributions to this journal).

The term irregular migrants is reserved in the Netherlands for those migrants who do not have a legal status to stay in the Netherlands and those who have to leave this country because their stay will otherwise become irregular. It involves, among others, rejected asylum seekers, migrants who have crossed the Dutch border and entered without a required visa, and migrants who have overstayed in the Netherlands after their residence permit/visa have expired or after the loss of their residence permit/visa.

\footnotetext{
${ }^{1}$ Miranda Boone is Professor of Penology and Penitentiary Law at the University of Groningen and Associate Professor of Criminology and Criminal Law at the University of Utrecht. Mieke Kox is conected to the Department of Criminology and Crimnal Law as a researcher. Contact adress: m.m.boone@uu.nl

2 The International Covenant on Civil and Political Rights, the Standard Minimum Rules for the Treatment of Prisoners of the United Nations, Recommendation No. R. (84) 12 of the Committee of Ministers from the Council of Europe to Member States Concerning Foreign Prisoners, the European prison rules and the European Committee for the Prevention of Torture and Inhuman or Degrading Treatment or Punishment state, for example, and in different terms, that detainees should have the possibility to prepare themselves for their return to society during a criminal sanction.
} 
These irregular migrants are, after the execution of the criminal sanction, supposed to return to their country of origin or to a third country in which their admission is guaranteed. However, expulsion to such a country cannot always be realized, due to several reasons such as the lack of the required travel documents (the so-called laissez passer), the lack of identity documents and the legal procedures for a residence permit which may be awaited in the Netherlands (see also Kox 2011 and the Ministry of the Interior and Kingdom Relations 2011). This means that criminal irregular migrants either return to their country of origin or a third country, or that they are released in the Netherlands. This fact only, complicates the implementation of the rehabilitation principle for irregular migrants and their preparation for their return to society during the execution of a criminal sanction in the Netherlands.

As yet, ample empirical data are available on this theme. This contribution gives an overview of the extent to which rehabilitation instruments and opportunities are accessible for irregular migrants who are serving a criminal sentence in the Netherlands. First, both the judicial and the practical meaning of the rehabilitation principle in the Netherlands are explained. Then, the number of irregular migrants in the Netherlands and their involvement in crime are described. Subsequently, the implementation of the rehabilitation principle for irregular migrants in Dutch legislation and policy is successively mapped for different criminal sanctions. Afterwards, the scarce information on how irregular migrants prepare themselves for their return to whatever society is summarized. And finally, we conclude this article with some considerations on the legitimacy of the lack of rehabilitation perspectives for irregular migrants in the Dutch criminal justice system.

\section{The meaning and implementation of the rehabilitation principle in the Netherlands}

The rehabilitation principle is considered to be a fundamental principle of penitentiary law in the Netherlands. It is enshrined in both Dutch penitentiary legislation and policy. Section 2 paragraph 2 of the Dutch Custodial Institutions Act [Penitentiaire Beginselenwet] includes a compulsory order for the government to prepare all detainees for their return to society during the execution of a criminal sanction. It states that sanctions 'should prepare the convict as much as possible for his return into society'. In the Netherlands this principle is not called rehabilitation, however, but resocialization. This re-socialization principle has formed, together with the principle of minimal restrictions, the heart of Dutch penitentiary law since 1953. Its introduction can be explained by the humanisation of the Dutch Prison System in general after the Second World War (Nelissen 2000).

The Dutch re-socialisation concept is as such unknown in English vocabulary. The literal meaning that can be found in the law is 'preparing for the return to society.' The intended content of this preparation has changed on several occasions over the years (Boone 2007). In the first few years after its introduction, the ambitions were very high: the re-socialization of prisoners had to increase their self-respect and selfconfidence, their feelings of responsibility, their own initiatives and social resistance (Franke 1990, p. 789). In later policy papers, a much less ambitious content was given to the principle due to scientific research that showed disappointing results and a changing penal climate (Boone 2007). Imprisonment had to be organized in such a way that it did not prevent the prisoner from reintegrating himself, a process that was no longer seen as the exclusive responsibility of the government and the prison 
authorities. Still, many activities were offered that could help prisoners to improve themselves. Instead of changing an offender's character, re-socialisation now required the teaching of concrete skills that could help offenders to attain a respectful position in society. In later years, emphasis was mainly put on work as a reintegrating activity. Only since the end of the last century have ambitions once again been increasing. The programme 'Push back recidivism' was introduced in both the Prison Service as well as the Probation Service, based on the What Works model by the Canadian scholars Andrews and Bonta. The aim of the programme was to diminish recidivism by screening offenders according to the criminogenic factors identified in the "What Works literature' and offering them behavioural interventions that have a demonstrable positive effect on recidivism. Only interventions that are tested by an acknowledgement committee modelled after the British accreditation panel are in fact subsidized (see Maguire, et al. 2010). Also, an ambitious Aftercare Programme was introduced for all former detainees, aiming to prepare them for their return to society with regard to four major fields: income, housing, identity papers and care.

To summarize, the meaning that was given to the re-socialisation concept changed over the years from rehabilitation in the sense of changing a person's thinking, or at least his or her behaviour, to what is understood as social rehabilitation or reintegration in the sense of giving a person practical tools to prepare him or herself for his/her return to society (Robinson 2009). Nowadays both aspects of the rehabilitation are brought into practice, but only for a selective group of offenders; however, bifurcation is nowadays a very dominant characteristic of Dutch sentencing practice (Cavadino \& Dignan 2006; Boone 2012), a characteristic that also affects irregular migrants as we will see below.

Contrary to, for example, Germany (Van Zyl Smit and Snacken 2009), the principle is generally not interpreted as a directly enforceable right for offenders. As a consequence, offenders cannot legally resort to the rehabilitation principle as such. However, offenders can claim some rights which follow from the rehabilitation principle during the execution of a custodial sentence. This concerns the following rights:

- contact with the outside world by post, personal visits and telephone;

- care consisting of spiritual care, health care, social care/assistance and nutrition, clothing and footwear;

- a meaningful day programme with work, education, recreation, library facilities, sports and exercise in the open air;

- complaint procedures; and

- leave.

Offenders are also offered some other instruments as a consequence of the rehabilitation principle during the execution of a custodial sanction. However, these following instruments cannot be claimed since these are not individually allocated rights.

- individualization: the consideration of the individual interests, needs and circumstances of detainees;

- differentiation: the distinction between regimes and arrangements for different groups of detainees;

- detention phasing: the placing of detainees in more open institutions to help them, on a step-by-step basis, to get used to their liberty;

- regionalization: the placing of detainees in their region of origin or the region where they want to settle in the future; 
- and aftercare: the continuation of care provided during the detention and the providing of support and supervision after prison.

\section{Irregular migrants and crime in the Netherlands}

In the Netherlands, irregular residence in itself is not a criminal offence. However, since December 2011 irregular migrants commit a misdemeanour if they remain in the country irregularly and if they have a so-called entry ban on the basis of Directive 2008/115/EC of the European Parliament and of the Council of 16 December 2008 on common standards and procedures in Member States for returning illegally staying third-country nationals (Staatsblad 2011 663, Parliamentary Documents 32 420). Such an entry ban means that irregular migrants are not allowed to be in the Netherlands and that they have to pay a maximum fine of $€ 3,800$ or be subject to imprisonment for a maximum term of six months whenever they are unable to pay this fine. In addition, the present Dutch Minister for Immigration and Asylum is planning to criminalize the irregular residency of all irregular migrants regardless of the imposition of an entry ban. He has proposed to punish an irregular stay with a fine, a sentence that can result in detention on remand if the irregular migrant is unable to pay this fine (Parliamentary documents 2010/11, 19637 no. 1435 p. 3-5). These plans were awaiting the approval of the Council of State [Raad van State] and the Dutch Parliament, but it is now uncertain what will happen to these plans due to the resignation of the Dutch government and the elections in September 2012. ${ }^{3}$

The number of irregular migrants in the Netherlands is not known because it is not possible to count irregular migrants due to their invisibility in society. However, some scholars have been able to estimate the number of irregular migrants in the Netherlands over the years. They come to the conclusion that between 60,667 and 133,624 irregular migrants were staying in the Netherlands in 2009 (Van der Heijden 2011). This estimation was based on data on the stop and arrests of irregular migrants according to the irregular immigration registers kept by the police and the Royal Netherlands Military Constabulary [Koninklijke Nederlandse Marechaussee]. This estimation method has been criticized, but it is the only available method so far (Van der Heijden 2005, Van der Leun and Illies 2008). Therefore, the results on the number of irregular migrants in the Netherlands are used within both academic and governmental publications.

The estimation does not provide any information on the involvement of irregular migrants in crime. As yet, no comprehensive data and figures are available on the involvement of irregular migrants in crime. Therefore it is not clear to what extent these irregular migrants are actually involved in crime. However, an advisory committee of the Ministry of Security and Justice, the Council for the Administration of Criminal Justice and Youth Protection [Raad voor Strafrechtstoepassing en Jeugdbescherming], has concluded that there are indications to assume that the gravity and the scale of crime among irregular migrants are moderate (Council for the Administration of Criminal Justice and Youth Protection 2010a). This conclusion was based on several studies on irregular residence and crime in the Netherlands (Kox 2010, Leerkes 2007, Engbersen and Van der Leun 2001). Most studies on this topic

\footnotetext{
${ }^{3}$ It should be noted that it is already possible to deprive irregular migrants of their liberty on the basis of the administrative Dutch Aliens Act 2000 [Vreemdelingenwet 2000]: these irregular migrants might be detained in immigration detention to await their removal due to their irregular stay on the basis of this act. This is not a criminal sanction, but an administrative measure although irregular migrants in immigration detention do have the feeling that they are being subjected to criminal detention. See for example Inspectie voor Sanctietoepassing 2010; Amnesty International; 2010, Council for the Administration of Criminal Justice and Protection of Juveniles; 2008 and Justitia et Pax; 2010.
} 
are based on the Aliens Administration System [Vreemdelingen Administratie Systeem, VAS] in which the arrests of irregular migrants in the Netherlands are registered. This concerns both irregular migrants who are arrested on the basis of aliens legislation and irregular migrants who are arrested on the basis of criminal law because of a suspicion of a criminal offence, traffic controls or other violations of Dutch law. On the basis of these registrations it is concluded that the involvement of irregular migrants in crime is moderate: most irregular migrants are, for example, registered in this system due to their irregular residency or misdemeanours and to a lesser extent due to offences. Irregular migrants are generally not involved in more serious crime according to these studies (Engbersen and Van der Leun 2001).

If irregular migrants are involved in crime, they mainly commit petty crimes such as shoplifting or theft, or they fulfil intermediary functions within the drugs circuit. The lack of other opportunities to earn a living due to exclusion from the labour market and social services is considered to be the main reason for the involvement of irregular migrants in crime. These crimes are therefore characterized as survival crimes (Engbersen et al. 1999; Engbersen et al. 1995; Engbersen et al. 2006). The term 'survival crime' has been refined by Leerkes in his dissertation on irregular residency and public safety in the Netherlands: he prefers the more neutral terms 'residence crime [verblijfscriminaliteit]' or 'subsistence crime [bestaanscriminaliteit]' to indicate that the lives of irregular migrants in the Netherlands are not directly threatened but that the delinquent behaviour of irregular migrants is a response to the restrictive living conditions to which irregular migrants are subjected (Leerkes 2007; Leerkes 2006). Currently, all three terms are used to describe the involvement of irregular migrants in crime.

The marginalization of irregular migrants is considered to be the main reason for their involvement in crime. Due to the intensification of Dutch migration policies and the exclusion of irregular migrants from facilities at formal institutions, irregular migrants are driven towards the margins of society. If they are not embedded in Dutch or ethnic networks, they might resort to crime if they see no other opportunities to earn a living. This is called the marginalization theory. This theory is elaborated in more detail by Leerkes, Engbersen and Van der Leun (2007): they have tested this theory by trying to exclude other possible explanations for the rise in registered crime among irregular migrants. They came to the conclusion that marginalization effects were the main reason for the rise in registered crime among irregular migrants between 1997 and 2003, although other factors such as criminal migration, developments in policing and police registration practices, status reclassification and demographic growth did also play a small part in this rise in crime in the aforementioned period. In the end, the scholars concluded as follows: "The empirical findings clearly falsify the social myth that irregular immigrants are responsible for a large share of all crimes in the Netherlands. While irregular immigrants appear to be overrepresented in crime statistics only recently, their criminal activities account for a small part of all crimes that are committed in the Netherlands (Leerkes, Engbersen and Van der Leun 2007, p. 163)."

\section{The rehabilitation principle for irregular migrants in legislation and policy}

In how far does the insecure residence status of irregular migrants affect their rehabilitation perspectives? So far, this has not been studied as such. This section provides an overview of the accessibility of both rehabilitative instruments carried out in the context of a prison sentence as sanctions with a predominantly rehabilitative 
character such as, for example, community sanctions. The sanctions that will be discussed are: imprisonment, measures for persistent offenders, measures for mentally-ill offenders and community service orders and the probation services.

\subsection{Prison sentences}

Prison sentences are a principal punishment for criminal offences in the Netherlands. These sentences may last from one day up to 30 years or, in extreme cases, life sentences. There are no mandatory sentences: the determination of the sanction is up to the court that takes several circumstances into account, in particular the severity of the offence, the circumstances under which the offence was committed and the personal and social background of the offender. If an offender is sentenced to imprisonment, he will be transferred to a prison in which the sanction will be executed. Prisons are differentiated by their security level and by the characteristics of some categories of detainees. So, besides minimum security prisons, limited security prison, normal security prisons and maximum security prisons, there also exist specific prisons for, for example, mentally-ill prisoners, mothers with children and prisoners with a terrorist background.

The day programme for prisoners consists of different activities such as, for example, visits to the library, creativity, sports/fitness, recreation, meals and remaining in their cells. Furthermore, prisoners have the right of contact with the outside world by post, personal visits and telephone, care, clothing and footwear, a meaningful day programme with work, education, recreation, library facilities, sports and exercise in the open air, to appeal in complaint procedures and to have leave. In addition, they may be entitled to rehabilitation instruments such as individualization, differentiation, detention phasing, regionalization and aftercare. In addition, it should be noted that prisoners may be eligible for conditional early release under special and general conditions such as mandatory participation in a programme assisting in a smooth return to society or providing special care, restrictions on someone's freedom to act or move, or electronic monitoring. As a part of the aforementioned Push Back Recidivism Programme, some prisoners can be offered behavioural interventions during their detention such as, for example, COVA (Cognitive Skills) Training. Almost all prisoners (except those sentenced to less than four months imprisonment) will be involved in an Aftercare Programme that will help them with housing, income after detention, medical care (if necessary) and identity papers.

Irregular migrants in the criminal justice system are subjected, relatively often, to custodial sanctions according to a study by Van Kalmthout et al. Besides, they are less often detained in prisons with a less restrictive security regime (Van Kalmthout et al. 2007). It is official policy to stimulate the detention of 'criminal' irregular migrants on either an administrative basis or a penal basis when they cannot be immediately expelled (Parliamentary documents 2007/08, 19 637, no. 1207). It should be noted that irregular migrants might be detained for 47 days on an administrative basis before the lawfulness of their detention is judicially reviewed by a judge (section 94 Aliens Act 2000). ${ }^{4}$

\footnotetext{
${ }^{4}$ In section 94 of the Aliens Act 2000 it is stated that the Minister of Justice should inform the court of the detention of the migrant within 28 days after the irregular migrant has been taken into custody; a judge should review the case not later than 14 days after he has received this information and he must come to a decision within 7 days after the review. This means that irregular migrants might be detained for 47 days before they know if their detention is lawful.
} 
Irregular migrants are in principle detained in specific penitentiary institutions. These institutions were established in 2009 because criminal irregular migrants were not supposed to return to Dutch society after the execution of their prison sentence (Government Gazette [Staatscourant] no. 56, 23 March 2009). Currently, there are two penitentiary institutions for criminal irregular migrants: the Veenhuizen penitentiary institution located at Esserheem for irregular migrants serving a custodial sentence of more than four months, and the Zeist detention centre for irregular migrants serving a (the remainder of a) custodial sentence of less than four months. ${ }^{5}$ In the former, special skills need to be taught to irregular migrants according to the regulation on which these special penitentiary institutions are based. These skills should help the migrants to prepare for their return to their country of origin This concerns, among others, vocational training, computer and language courses, and carpentry and painting skills (Government Gazette [Staatscourant] no. 56, 23 March 2009). However, these activities are hardly available as we will show later.

Irregular migrants remain in Esserheem until their prison sentence has no more than four months still to run. Then, they are transferred to the Zeist detention centre which also houses irregular migrants who have been sentenced to a custodial sanction of four months or less. At this detention centre, the Repatriation and Departure Service is supposed to work more actively on the expulsion of criminal irregular migrants from the Netherlands which should result in the actual departure of criminal irregular migrants from the Netherlands. If a migrant cannot be expelled during the execution of the criminal sanction, he may subsequently be detained in immigration detention with the purpose of removal on the basis of immigration law.

According to information by mail of the Custodial Institutions Service [Dienst Justitiele Inrichtingen, DJI], in September 2011 plusminus 1150 persons without a residence status were detained in penitentiairy institutions on a criminal ground. Irregular migrants in the criminal justice system are not always detained in the abovementioned special penitentiary institutions, however, since their residence status is not always clear. In such a case, the (irregular) migrant will be detained in an ordinary penitentiary institution instead of in a specific penitentiary institution. In these institutions, regular rehabilitation facilities are offered to detainees, but irregular migrants are often excluded from these facilities. Regardless of the penitentiary institutions in which irregular migrants are detained, they are formally excluded from many re-socialization activities. They are, for example, not eligible for participation in the aforementioned Push Back Recidivism programme. Irregular migrants whose expulsion after their detention is certain are not eligible for leave (Section 4(1) Regeling tijdelijk verlaten van de inrichting (Temporary Leave Regulation)). And such arguments for the exclusion of irregular migrants from re-socialization instruments can also be found in penal policies and regulations regarding individualization, differentiation, detention phasing and aftercare (Regeling selectie, plaatsing en overplaatsing gedetineerden, Aanwijzing voorwaardelijke invrijheidstelling and Parliamentary documents 2002/03, 19637 no. 704 p. 8). However, these arguments are not unambiguous: it might for example be doubted whether the expulsion of an irregular migrant is certain since a majority of irregular migrants cannot be expelled. And also the irregularity of the residency of a migrant might give rise to discussion since the status of a migrant is not fixed. Nevertheless, it is clear that is it the government's intention to exclude irregular migrants from re-

\footnotetext{
${ }^{5}$ This, however is a temporarily location. Irregular migrants will be replaced to the penitentiairy institution in Alphen aan den Rijn as soon as it is rebuild.
} 
socialization rights and instruments and therefore such regulations and penal policies have been introduced in recent years.

Finally, it is noteworthy that irregular migrants are no longer eligible for conditional release: these migrants are supposed to serve their full sentence (section 15, subsection 2 CC). However, the sentence may be interrupted if the irregular migrant will leave the Netherlands immediately and if he will never return to the country again (Aanwijzing voorwaardelijke invrijheidssteling (Staatscourant no. 5379, 2012). This decision is taken by the Dutch Minister of Security and Justice and/or by the Custodial Institutions Service [Dienst Justitiele Inrichtingen, DJI]. Whenever the irregular migrant returns to this country, he will have to serve the remainder of the custodial sentence. This policy was introduced in April 2012.

\subsection{Sanctions for persistent offenders}

In 2004, a criminal measure for persistent offenders was introduced in the Netherlands: the Institution for Repeat Offenders [Inrichting voor Stelselmatige Daders, ISD]. This measure makes it possible to detain persistent offenders above the age of 18 for a maximum of two years if they have been sentenced to a custodial sentence at least three times in the five years prior to the offence. The aim of the measure is to prevent criminal behaviour by prolonged detention in special penitentiary institutions in which rehabilitation is central. For that reason, special intramural and extramural programmes are offered to detainees during their detention such as group therapy, addiction treatment and financial guidance. The measure is not a sentence as such, it is simply considered to be a measure. This has as a consequence that regular principles regarding proportionality between the seriousness of the criminal offence and the length of the detention are less relevant. The measure aims to safeguard society by detaining persistent offenders, on the one hand, and preventing the suspect from committing repeat offences by treating him, on the other. Such a measure already existed for addicted offenders who committed their crimes due to their addiction, but this measure was extended to all persistent offenders. ${ }^{6}$

Irregular migrants used to be excluded from this measure. However, since 2008 irregular migrants may be subjected to this measure on the basis of a prosecutorial sentencing guideline. Unlike other persistent offenders, they do not have rehabilitation opportunities during the execution of this security measure: they are not eligible for those extramural programmes that are aimed at behavioural change since they do not have the right to use the regular facilities in Dutch society. They are only eligible for some intramural activities. This means that criminal irregular migrants are excluded from the essence of this criminal measure, namely those rehabilitation facilities which are aimed at behavioural change to prevent recidivism (see also the Council for the Administration of Criminal Justice and Youth Protection 2010b).

This situation is not surprising given the justification of the Secretary of State for introducing this measure in 2008 for irregular migrants. She stated that, in order to prevent irregular migrants who cannot (yet) be expelled from committing offences, prolonged detention should be applied in order to enhance the possibility of a successful expulsion. Under the motto 'expulsion or detainment of criminal irregular

\footnotetext{
${ }^{6}$ It should be noted that this measure has been repeatedly criticized since the interventions focusing on underlying addictions or psychological problems are only available to a limited number or extremely motivated persistent offenders. Pure a simple incarceration for two years without any intervention is the answer for most of this target group, according to Moerings. See Moerings 2007.
} 
migrants' the criminal measure for persistent offenders is imposed on irregular migrants in an adapted form since the measure is not meant to prepare them for their return to Dutch society (Parliamentary documents 2007/08, 19637 no. 1207).

\subsection{Sanctions for mentally-ill offenders}

The Netherlands is known for a special sanction for offenders who suffer from mental illness and who commit a crime under the influence of this illness: detention under a hospital order [terbeschikkingstelling, TBS]. It may be imposed if the following criteria are met:

1) the individual has committed a serious offence punishable by at least four years imprisonment (or any of a number of other stipulated offences);

2) there is evidence of a mental disorder at the time of the offence and bearing some relation to it; and

3) there is the expectation that other offences will be committed in the future due to the same disorder.

The aim of the measure is two fold: to protect society against dangerous criminals and to treat offenders and prepare them for their return to society. The measure is imposed for an unlimited period of time. Periodically, the continuation of the measure is reviewed although the measure may be lifelong. The use of this protection measure has increased dramatically since 1990 and is nowadays imposed on about 200 offenders a year (see also Koenraadt and Mooij 2007).

Criminal irregular migrants are hardly eligible for this measure. In the past, this hospital order was also imposed on criminal irregular migrants for whom treatment was considered necessary to prevent recidivism. However, the hospital order could not be effectively executed due to problems in the treatment regarding language problems, cultural barriers and, in particular, the lack of possibilities for leave. Therefore, the risk was present that in practice irregular migrants would be sentenced to life imprisonment as they could not be effectively treated. This was considered undesirable by the Minister due to the high costs, the scarce treatment capacity and the rehabilitation aim of this measure. In 2009, the Secretary of State therefore decided to develop a regulation so as to no longer impose this measure on criminal irregular migrants, even though she had stated in 2008 that social safety and international moral obligations were the basis of this measure and that it was of no consequence whether an offender remained irregularly in the Netherlands (Parliamentary documents 2007/08, 19637 no. 1207). The current policy is that in principle - whenever possible and responsibly - no hospital order will be imposed on irregular migrants or migrants whose residency will become irregular after the execution of the measure (Parliamentary documents 2009/10, 19637 no. 1306). This principle is enshrined in a prosecutorial sentencing guideline and in Dutch policy papers which should be used by judges when they impose a sanction. This means that the hospital order is only very exceptionally imposed on dangerous and mentally-ill offenders who are or will be declared a so-called undesirable alien ${ }^{7}$ and on irregular migrants who are expected to return to the Netherlands after their expulsion.

\footnotetext{
${ }^{7}$ Irregular or regular migrants can be labelled as an 'undesirable alien' under Section 197 of the Criminal Act if they, for example, twice violate the Aliens Act 2000, or after the imposition of an unconditional prison sentence for a crime carrying a sentence of three years imprisonment or more. These migrants will lose their residence permit and are punishable for being in the Netherlands while they are declared an undesirable alien.
} 


\subsection{Community service orders}

In 2001, community service orders were introduced in the Netherlands as an independent principal penalty (Boone 2010). They can be imposed for a maximum of 240 hours and are considered to be - in terms of their severity - a sanction which lies somewhere in between a prison sentence and a fine. Default detention is imposed if the offender does not carry out the community service order in a satisfactory way. Nowadays, more than 30,000 csos are imposed by either a judge or the prosecution service. In the light of the topic at stake, it is interesting that Wermink et al. found that offenders on whom a community sentence is imposed are five times more likely to be born in the Netherlands compared to offenders sentenced to a short term of imprisonment (Wermink at al. 2009).

The execution of community service orders for irregular migrants has been problematic since the beginning of the century (Boone 2002). Offenders have to be able to identify themselves on the community service order project, a requirement that automatically discriminates against irregular migrants. Despite a letter by the Minister of Justice to the effect that the Probation Service had to carry out their services for irregular migrants in the same way as for other offenders, irregular migrants kept being sent away, despite a verdict by the judge in which it was stated that a community service order was imposed. Times have changed, however, and since 2009 irregular migrants are formally not eligible for community service orders since an irregular residence in the Netherlands is considered to be a counter-indication for the imposition of this measure. Whether judges do impose community service orders on this category of offenders despite the existence of this counter-indication is not known, but it is predictable that if they do, irregular migrants will still be discriminated because of the impossibility to identify themselves.

\subsection{Probation services}

Probation organizations in the Netherlands have the following tasks: diagnosis and advice, supervision of conditional sanction modalities, carrying out behavioural interventions and performing task penalties. The probation services can only perform probation activities that are requested by the judicial authorities: this means that there is no voluntary contact with offenders (Kalmthout, A.M. van, and Durnescu 2008).

Irregular migrants are excluded from probation services in the Netherlands. A former Minister of Immigration Affairs and Integration stated in 2002 that the Dutch Probation Service does not offer any support and/or supervision that facilitates the reintegration of irregular migrants in the criminal justice system (Parliamentary documents 2002/03, 19637 no. 704). So far, this point of departure has not changed which means that irregular migrants in the criminal justice system do not receive any probation services during or after the execution of their sanction which facilitates their return to society.

\section{The rehabilitation principle for irregular migrants in practice}

The previous section discussed the rehabilitation principle for irregular migrants in Dutch legislation and policy. This section focuses on the rehabilitation principle for irregular migrants in the Netherlands in practice. There are hardly any recent empirical studies that focus solely on this group of offenders, with the exception of an Advisory Report by the Council for the Administration of Criminal Justice and Youth 
Protection (2010a) concerning the positions of detainees in the special penitentiary institutions for irregular migrants who have committed a criminal offence. The Council concluded that the opportunities for this category of detainees to prepare them for their return to society fell short with respect to the facilities in this special reception unit. Work and education were insufficiently available or accessible to criminal irregular migrants and the activities were not aimed at the facilitation of the departure of the migrant. Preparing for a return to society was thus hardly possible in these prisons. Although irregular migrants had the formal right to prepare themselves for their return to society, the Council's Advisory Report showed that these opportunities were very limited in practice (Council for the Administration of Criminal Justice and Youth Protection 2010a).

A study by Van Kalmthout et al. concerning the position of foreigners in European prisons shows that foreigners, including irregular migrants in the criminal justice system, are, in comparison to Dutch offenders, overrepresented in prisons and penitentiary institutions with a closed character and sober conditions, facilities and day programmes and with limited work and education programmes being offered (Van Kalmthout et al. 2007). The study by Post on detention and cultural diversity proves that foreigners face difficulties in claiming their rights due to the unintended effects of the regulation, a lack of resources, misunderstandings, ignorance, miscommunication and practical impossibilities. As a result, foreign detainees make less use of their rights than Dutch detainees. This is reflected in the transmission of information, contact with the outside world, consular and legal assistance, participation in education and other vocational activities, leave and detention phasing. This has an inevitable impact on the rehabilitation opportunities for foreigners in detention in the Netherlands, including irregular migrants (Post 2005). This conclusion is also drawn in the aforementioned study by Van Kalmthout et al. So, the scarce information on the implementation of the rehabilitation principle for criminal irregular migrants in the Netherlands makes clear that the effectuation of rehabilitation opportunities for criminal irregular migrants is seriously hampered during the execution of prison sentences.

\section{To conclude: the legitimacy of the exclusion of irregular migrants from rehabilitation opportunities}

This contribution makes clear that irregular migrants in the criminal justice system and migrants whose stay will become irregular due to a criminal conviction are largely excluded from criminal sanctions in which rehabilitation is central and/or from rehabilitation opportunities during the implementation of a criminal sanction. They are, for example, excluded from community service orders and probation services and they are not eligible for the rehabilitation instruments during prison sentences, measures for persistent offenders and measures for mentally-ill offenders. This exclusion is mainly enshrined in prosecutorial sentencing guidelines. The scarce empirical information shows that foreigners, including irregular migrants, also face difficulties in claiming those rights which are part of the implementation of the rehabilitation principle during the execution of a criminal sanction in practice. Irregular migrants are thus not offered many opportunities to prepare themselves for their return to society even though the rehabilitation principle is enshrined in both international and national legislation, and even though the importance of the rehabilitation principle regarding the prevention of recidivism is repeatedly shown in academic studies and even the importance of rehabilitation opportunities are recognized in Dutch penal policies nowadays. 
It should be noted that re-socialization opportunities and instruments used to be available for irregular migrants in immigration detention. The regulations in which irregular migrants are excluded from re-socialization are relatively new: they have all been developed since the turn of the century. And also in immigration detention, there used to be more opportunities for irregular migrants to prepare themselves for their return to society: in the Tilburg penitentiary institution which used to be used for immigration detention, for example, vocational training and more activities were available for irregular migrants (Van Kalmthout 2007). However, these training programmes and activities have been abolished and are currently hardly available in immigration detention. Very recently and due to the many critical reports and articles discussed in this paper, small-scale opportunities have become available for irregular migrants who are being detained in the Rotterdam immigration detention centre to enable them to orientate themselves concerning their future. There are also more opportunities for detainees in self-education and to have access to selected websites. (Inspectie voor de Sanctietoepassing 2012).

So far, these facilities are not available to irregular migrants in the criminal justice system, however. The reason for largely excluding irregular migrants from rehabilitation opportunities is that irregular migrants are not supposed to return to Dutch society since their stay is or has become irregular. It is assumed that these migrants will return to their country of origin or another country in which the migrants' admission is guaranteed. Preparation for their return to this other society is therefore not considered necessary. However, it is a fiction that irregular migrants leave the Netherlands after detention since a substantial number of irregular migrants cannot be expelled from the Netherlands. ${ }^{8}$ Besides, the highest Dutch legal authority stated back in 1987 that the rehabilitation principle also applies to people with nonDutch nationality: every detainee, also those detainees with non-Dutch nationality, has the right to be offered rehabilitation, regardless of the society to which they will return and even though it is uncertain whether they will return to Dutch society (The Supreme Court of the Netherlands [Hoge Raad], January 17, 1987: NJ 1987, 12767 p. 405).

This contribution makes clear that the position of irregular migrants in the criminal justice system in the Netherlands is not in accordance with the elaboration of the rehabilitation principle in Dutch and international law. Like other detainees, irregular migrants should have the possibility to prepare themselves for their return to society and to prevent their recidivism if necessary. Based on this point of departure, a different rehabilitation concept should be developed that is not mainly nation-based, but also prepares for a return to another or unknown country. What could speed up this operation is information on how irregular migrants actually prepare themselves for their return to society during the execution of a criminal sanction. What are their needs and what frustrates them? More information is therefore necessary concerning the position of irregular migrants in the criminal justice system in practice and their position in society after completing their sentence.

\footnotetext{
${ }^{8}$ In 2010, 49\% of migrants in immigration detention were expelled either to their country of origin or within Europe and $6 \%$ of migrants in immigration detention during this year returned independently with the assistance of the International Organization for Migration (IOM). The numbers of irregular migrants who are successfully expelled after their term of imprisonmentn is not clear. According to the Repatriation and Departure Service $70 \%$ of irregular migrants within the criminal justice system were expelled in the first half of $2011,30 \%$ of these migrants were released within the Netherlands. However, these figures only imply irregular migrants within its caseload: irregular migrants in immigration detention who are not part of the caseload of the Repatriation and Departure Service are not included in these figures. See also Kox, 2011 p. 80-81.
} 


\section{References}

Amnesty International (2010) Vreemdelingendetentie: in strijd met mensenrechten [Immigration detention: in conflict with human rights], Amsterdam: Amnesty International.

Boone, Miranda (2002), Leren diversifiëren. Reclassering en culturele diversiteit, Willem Pompe Instituut, Utrecht, 2002

Boone, Miranda (2007), Selective Rehabilitation, in: Dutch Prisons, BJU Legal Publishers The Hague 2007, p. 231-249.

Boone, Miranda (2010), Only for minor offences, Community service in the Netherlands, European Journal of Probation, Volume 2, nr. 1, p. 22-40.

Cavadino, Michael and James Dignan (2006), Penal Systems. A comparative approach, London: Sage

Council for the Administration of Criminal Justice and Youth Protection (2008) Vreemdelingenbewaring: advies [Immigration detention: advisory report]. The Hague: Council for the Administration of Criminal Justice and Youth Protection.

Council for the Administration of Criminal Justice and Youth Protection (2010a), Regimesontwikkeling in de inrichtingen voor strafrechtelijk gedetineerde vreemdelingen: advies [Regime Developments in institutions for irregular migrants: Advisory report]. The Hague: Council for the Administration of Criminal Justice and Youth Protection.

Council for the Administration of Criminal Justice and Youth Protection (2010b) De ISD-maatregel voor vreemdelingen zonder verblijfstitel: advies [The persistent offenders measure for irregular migrants: advisory report]. The Hague: Council for the Administration of Criminal Justice and Youth Protection.

Custodial Institutions Agency and the Dutch Probation Organizations (2007) Programma Terugdringen Recidive: Draaiboek samenwerking Gevangeniswezen \& Reclassering [The Push Back Recidivism Programme: Prison \& Probation cooperation roadmap]. The Hague.

Engbersen, G., Leun, J. van der, and Willems, P. (1995) De verwevenheid van illegaliteit en criminaliteit [The interrelationship of irregularity and criminality]. Utrecht: Onderzoeksschool AWSB Research Papers.

Engbersen, G., Leun, J. van der, Staring, R. and Kehla, J. (1999) De ongekende stad 2: Inbedding en uitsluiting van illegale vreemdelingen [The unknown city 2: embeddednes and exclusion of irregular migrants]. Amsterdam: Boom.

Engbersen, G. and Leun, J. van der (2001) 'The social construction of illegality and crime', European Journal on Criminal Policy and Research 9: 51-70.

Engbersen, G., San, M. van and Leerkes, A. (2006) A room with a view: Irregular immigrants in the legal capital of the world. Ethnography SAGE Publications, London 7 (2): 209-242.

Franke, Herman (1990), Twee eeuwen gevangen, Utrecht: Het Spectrum 1990.

Heijden, P. van der, Gils, G. van, Cruijff, M. and Hessen, D. (2006) Een schatting van het aantal in Nederland verblijvende illegale vreemdelingen in 2005 [An estimation of the number of irregular migrants in the Netherlands in 2005]. Utrecht: IOPS-Utrecht, University Utrecht.

Heijden, P.G.M. van der, Cruyff, M., Gils, G.H.C. van (2011) Schattingen illegaal in Nederland verblijvende vreemdelingen 2009 [Estimates of the number of irregular migrants in the Netherlands 2009]. Utrecht: Research and Documentation Centre of the Ministry of Security and Justice. 
Inspectie voor Sanctietoepassing (2010) De tenuitvoerlegging van de vreemdelingenbewaring: drie Detentiecentra doorgelicht [The execution of immigration detention: three Detention Centres examined]. The Hague: Ministry of Justice.

Inspectie voor de Sanctietoepassing (2012) Detentiecentrum Rotterdam: inspectierapport doorlichting [Rotterdam Detention Centre: inspection report investigation]. The Hague: Ministry of Security and Justice.

Justitia et Pax (2010) Humaniteit in vreemdelingenbewaring: ervaringen van het r.k. justitiepastoraat [Humanity in immigration detention: experiences of Catholic pastoral care]. The Hague: Justitia et Pax Nederland.

Kalmthout, A.M. van (2007) 'Het regiem van de vreemdelingenbewaring: de balans na 25 jaar [The regime of immigration detention: a balance after 25 years]', Justitiële Verkenningen 33 (4): 89-102.

Kalmthout, A.M., Hofstee-van der Meulen, F.B.A.M. and Dunkel, F. (ed.) (2007) Foreigners in European Prisons. Tilburg: Wolf Legal Publishers.

Kalmthout, A.M. van, and Durnescu, I. (eds.)(2008) Probation in Europe. Tilburg: Wolf Legal Publishers.

Koenraadt, F. and Mooi, A. (2007), Mentally ill offenders, in Boone, M. and Moerings, M., Dutch prisons. The Hague: Boom Juridische Uitgevers.

Kox, M. (2010) Het leven gaat door: een onderzoek naar de effecten van het illegalenbeleid op het leven van uitgeprocedeerde asielzoekers in Utrecht [Life goes on: a study on the effects of migration policies on the lives of rejected asylum seekers in Utrecht]. Utrecht: Stichting LOS.

Kox, M. (2011) Leaving detention... A study on the influence of immigration detention on migrants' decision-making processes regarding return. The Hague: International Organization for Migration.

Leerkes, A., Engbersen, G. and Leun, J. van der (2007) The rise in crime among irregular immigrants: The marginalisation thesis in question, in: Leerkes, A. (2007) Illegaal verblijf en veiligheid in Nederland [Irregular residence and security in the Netherlands]. Amsterdam: Dissertation University of Amsterdam.

Leerkes, A. (2007) 'I am just trying to live my life; statusdilemma's en criminaliteit bij illegale migranten met een asielachtergrond II am just trying to live my life; status dilemmas and crime amongst irregular migrants with an asylum history]', Migrantenstudies 23 (3): 180-206.

Leerkes, A. (2007), Illegaal verblijf en veiligheid in Nederland [Irregular residence and security in the Netherlands]. Amsterdam: Dissertation University of Amsterdam.

Leun, J. van der, en Illies, M. (2008) Undocumented Migration, Counting the Uncountable: Data and Trends across Europe, Country report The Netherlands. Clandestino.

Kingdom Relations (2011) Rapportage Vreemdelingenketen Januari-Juni 2011 [Report of the Immigration Chain January-June 2011]. The Hague: Ministry of the Interior and Kingdom Relations.

McNeill, Fergus, Peter Raynor and Chris Trotter (2010): Offender Supervision, New directions in theory, research and practice, Oxon and New York: Willan Publishing.

Moerings, M. (2007) Persistent offenders, in Boone, M. and Moerings, M. (2007) Dutch prisons, The Hague: Boom Juridische Uitgevers.

Nelissen (2001), Peter, Kansarme en kansrijke gedetineerden, selectiviteit en tweedeling in penitentiaire inrichtingen, Justitiële Verkenningen, nr. 6, p. 66-76. 
Post, M. (2005) Detentie en culturele diversiteit [Detention and cultural diversity]. The Hague: Boom Legal Publishers.

Robinson, Gwen and Iain Crow (2009), Offender rehabilitation, Theory, Research and Practice, Sage London.

Uit Beijerse, J. and Van Swaaningen, R. (2007), Non-custodial sanctions, in Boone, M. and Moerings, M., Dutch prisons. The Hague: Boom Juridische Uitgevers.

Van Zyl Smit, D. and S. Snacken (2009), Principles of European Prison Law and Policy; Penology and Human Rights. Oxford: Oxford University Press. 